\title{
Two new species of Ptinidae (Coleoptera) from Eocene Baltic amber
}

\author{
JiŘí Háva ${ }^{1,2}$ \& Petr ZAHRADNÍK ${ }^{3}$ \\ ${ }^{1}$ Daugavpils University, Institute of Life Sciences and Technology, \\ Department of Biosystematics, Vienības Str. 13, Daugavpils, LV-5401, Latvia \\ 2Private Entomological Laboratory and Collection, \\ Rýznerova 37, CZ - 25262 Únětice u Prahy, Praha-západ, \\ Czech Republic e-mail: jh.dermestidae@volny.cz \\ ${ }^{3}$ Forestry and Game Management Research Institute, \\ Strnady 136, CZ-156 00 Praha 5-Zbraslav, Czech Republic \\ e-mail: zahradnik@vulhm.cz
}

Háva, J. \& Zahdradník, P.: Two new species of Ptinidae (Coleoptera) from Eocene Baltic amber.

Abstract: Two new species, Ernobius arturi sp. nov. and Xestobium michalskii sp. nov. are described from Eocene Baltic amber.

Keywords: Taxonomy, new species, Coleoptera, Ptinidae, Ernobius, Xestobium, Baltic Amber, Poland

\section{Introduction}

The family Ptinidae (Coleoptera) from Baltic amber have been recently studied (Alekseev 2012, 2013, 2014, Alekseev \& Bukejs 2019a,b, Alekseev et al. 2019, Bukejs \& Alekseev 2015, Bukejs et al. 2017, 2018, Háva \& Zahradník 2019a, b, 2020a,b, ZAHRADNíK \& HÁvA 2014, 2017, 2019).

Two new species belonging to genera Ernobius C. G. Thomson, 1859 and Xestobium Motschulsky, 1845 are described here from Eocene Baltic amber collected in Poland.

\section{Material and methods}

The habitus photograph was made by a digital camera using Canon EOS 4000D on stereobinocular microscope Nikon SMZ800 + SMZ1500 + PLAN APO lens.

The type material is deposited in the following collection:

JHAC - Private Entomological Laboratory and Collection, Jiří Háva, Únětice u Prahy, Prague west, Czech Republic.

Each specimen of the new species described here is provided with a red, printed label showing the following text: HOLOTYPE Ernobius arturi sp. nov. and Xestobium michalskii sp. nov. J. Háva \& P. Zahradník det. 2020. 


\section{Results}

\section{Subfamily Ernobiinae}

\section{Ernobius arturi sp. nov.}

Type material: Holotype (unsexed): Amber inclusion No. 5652, Poland, Gdansk city area, (JHAC).

The complete beetle is included in a transparent amber piece, with dimensions of $13 \times 8 \times 4 \mathrm{~mm}$. Syninclusions consist of numerous minute organic particles.

Description of holotype: Body oval, shine (Fig. 1), transversally and longitudinally convex, body length $1.4 \mathrm{~mm}$, the greatest width $0.6 \mathrm{~mm}$ (in amber situation). Pronotum, head, elytra, abdomen and legs black, antennae very dark brownish-black.

Head hypognathous, almost flattened, finely punctuated, punctures almost touched. Eyes large, rounded, slightly convex, glabrous. Antennae with 11- antennomeres, antennal club with 3- antennomeres (Fig. 2), with long setae. Palpi short, dark brownishblack.

Pronotum (Fig. 3) transverse, coarsely punctuated, shiny. The greatest width very shortly before base. Posterior angles obtusely rounded (in dorsal view); anterior part of pronotum slightly raised.

Elytra shortly oval, shining, with distinct shoulders, with very short setation. Each elytron with striae consisting of very small poorly defined punctures discally, defined near apex of elytron, and with two lateral striae consisting of large punctures, reaching to elytral apex. Prosternum and metasternum with large individual punctures laterally.

Legs robust and short, black, tarsi brownish-black.

All ventrites of the same length, with small punctures medially.

Differential diagnosis: The new fossil species differs from other known amber species by the structure of antennae and elytral puctuation; it is very similar to Ernobius barticus Alekseev, 2014 but differs from it by the black body colour and structure of antennae.

Etymology: Patronymic, dedicated to amber specialist Artur Michalski (Wroclaw, Poland).

\section{Subfamily Ernobiinae}

\section{Xestobium michalskii sp. nov.}

Type material: Holotype (unsexed): Amber inclusion No. 5390, Poland, Gdansk city area, (JHAC).

Complete beetle is included in transparent amber piece, with dimensions of $39 \times 15 \times 5$ mm. Syninclusions consist of two specimens of Nematocera (Diptera), and numerous small to minute organic particles.

Description of holotype: Body shortly elongate, matt, transversally and longitudinally convex, body length $2.0 \mathrm{~mm}$ (in amber situation), width not measured. Pronotum, head, elytra and abdomen black, antennae and legs brown (Fig. 4-5).

Head hypognathous, almost flattened, finely punctuated. Eyes large, rounded, slightly convex, glabrous. Antennae with 11- antennomeres, antennal club with 3- antennomeres (Fig. 6). Palpi very short and broad, brown. 

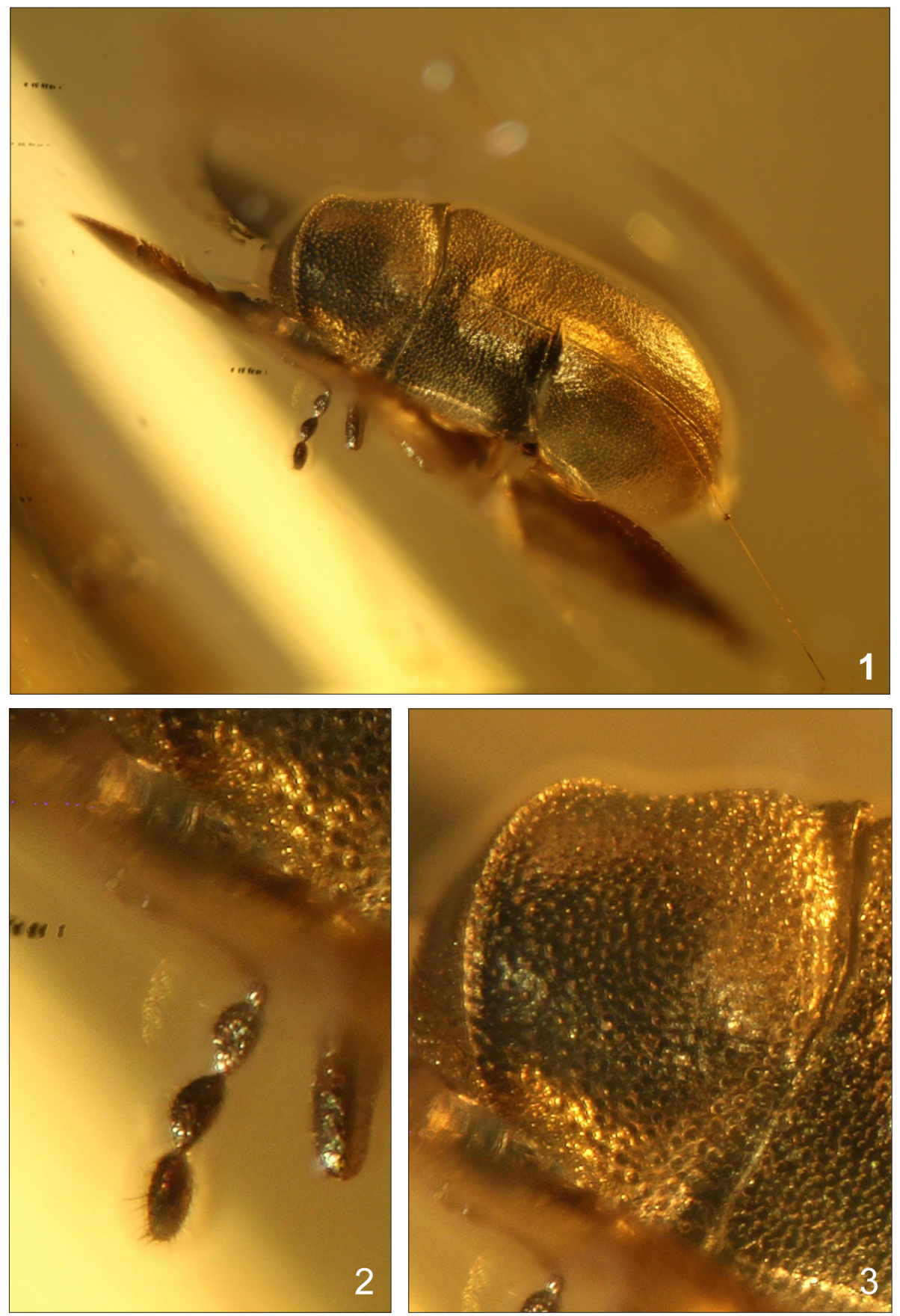

Figs. 1-3: Ernobius arturi sp. nov.: 1- habitus dorsal view; 2- antenna; 3- pronotum (photo by A. Michalskii) 

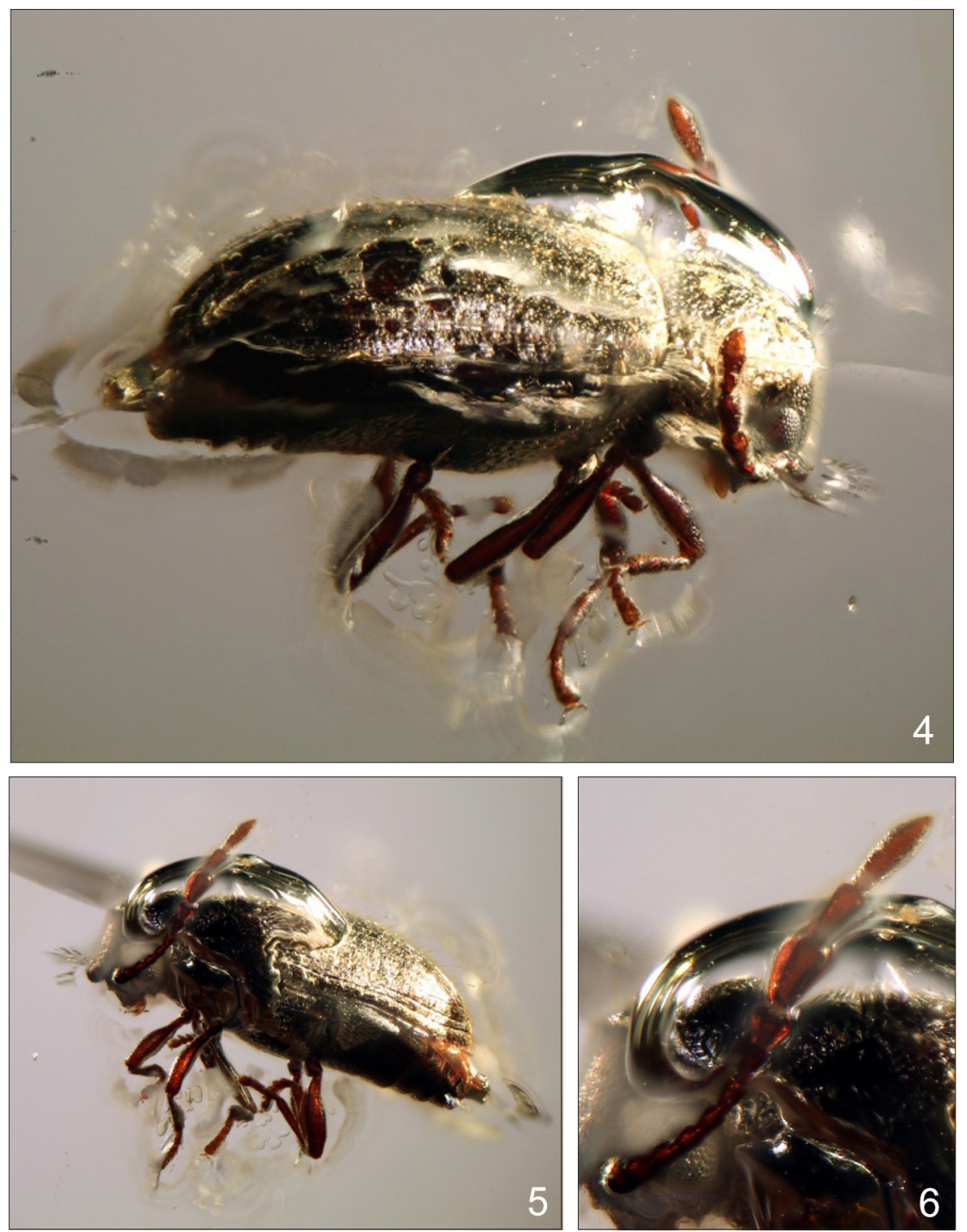

Figs. 4-6: Xestobium michalskii sp. nov.: 4- lateral view, right; 5- lateral view, left; 6- antenna (photo by A. Michalskii)

Pronotum transverse, coarsely punctuated. The greatest width very shortly before base. Posterior angels obtusely rounded (in dorsal view).

Elytra shortly oval, with distinct shoulders, covered by very short, decumbent setation. Each elytron with 12 striae very narrow, reaching to apex. Striae consist of very small punctures, their diameter twice as large as distance between them. Interstriae slightly wider than striae. Epipleuron very short.

Metasternum with very large punctures. 
Legs brown, robust and short.

All ventrites of the same length; ventrites I and II with large punctures, ventrites III-V with small punctures.

Differential diagnosis: The genus Xestobium was mentioned from Baltic amber by Larsson (1978) and Spahr (1981) as a unnamed species. The mentioned specimen represents the first described species from amber. The new species differs from the recently described species by the structure of the elytral striation, and structure of antennae.

Etymology: Patronymic, dedicated to amber specialist Artur Michalski (Wroclaw, Poland).
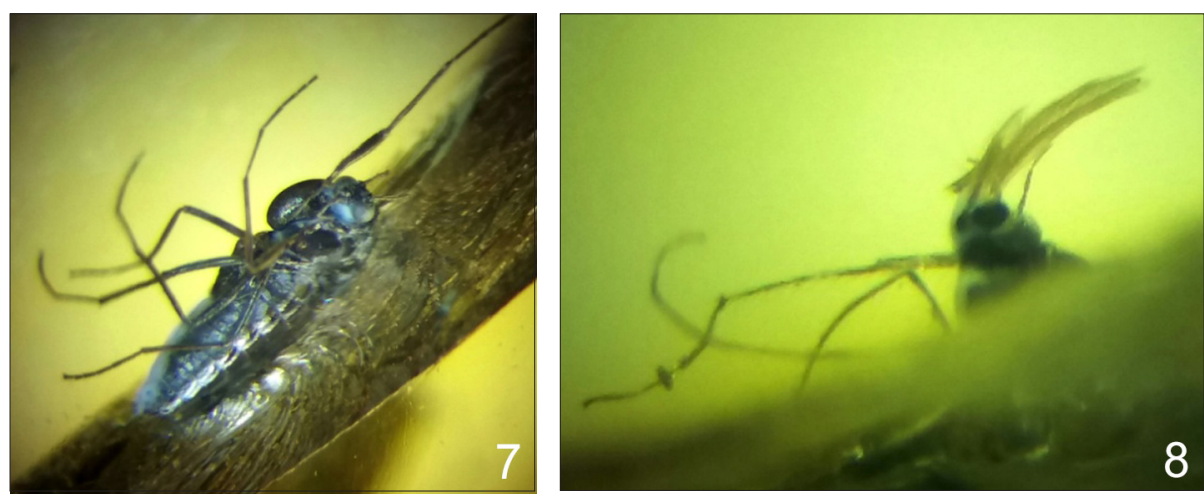

Figs. 7-8: Syninclusions specimens of Nematocera (Diptera)

(photo by J. Háva)

\section{Acknowledgements}

We are indebted to Artur Michalski (Poland) for providing us with the interesting material and to Miloslav Rakovič (Czech Republic) for linguistic correction. The paper was supported by the Ministry of Agriculture of the Czech Republic, institutional support MZE-RO0118. 


\section{References}

Alekseev, V. I. 2012: Sucinoptinus bukejsi sp. nov. (Coleoptera: Ptinidae: Ptinini), the second species of the Tertiary genus from the Baltic amber. - Baltic Journal of Coleopterology 12: 145-148.

Alekseev, V. I. 2013: The beetles (Insecta: Coleoptera) of Baltic amber: the checklist of described species and preliminary analysis of biodiversity. - Zoology and Ecology 23: 5-12. DOI: http://dx.doi.org/10.1080/216 58005.2013.769717

Alekseev, V. I. 2014: New fossil species of Ptinidae (Insecta: Coleoptera) in Baltic Amber (Tertiary, Eocene). - Zoology and Ecology 24(3):239-255. DOI: http://dx.doi.org/10.1080/21658005.2014.909154

Alekseev, V. I. \& Bukess, A. 2019a: Two new species of Xyletinus Latreille (Ptinidae: Xyletininae) in Eocene Baltic amber. - Zootaxa 4668(4): 525-534. DOI: https://doi.org/10.11646/zootaxa.4668.4.5

Alekseev, V. I. \& Bukess, A. 2019b: Xyletinus (s. str.) thienemanni sp. nov., a new species of Xyletininae (Coleoptera: Ptinidae) from Eocene baltic amber. - Acta Biologica Universitatis Daugavpiliensis 19(1): 31-35.

Alekseev, V. I., Bukejs, A. \& Bellés, X. 2019: Dignoptinus, a new genus for fossil Dignomus regiomontanus Alekseev from Eocene Baltic amber, and new status for Bruchoptinus Reitter and Pseudoptinus Reitter (Coleoptera: Ptinidae). - Fossil Record 22: 65-72. DOI: https://doi.org/10.5194/fr-22-65-2019

Bukejs, A. \& Alekseev, V. I. 2015: A second Eocene species of death-watch beetle belonging to the genus

Microbregma Seidlitz (Coleoptera: Bostrichoidea) with a check list of fossil Ptinidae. - Zootaxa 3947(4): 553 562. DOI: http://dx.doi.org/10.11646/zootaxa.3947.4.6

Bukejs, A., Alekseev V. I., Cooper, D. M. L., King, G. A. \& McKellar, R. C. 2017: Contributions to the palaeofauna of Ptinidae (Coleoptera) known from Baltic Amber. - Zootaxa 4344(1): 181-188. DOI: https:// doi.org/10.11646/zootaxa.4344.1.12

Bukejs, A., Bellés, X. \& Alekseev, V. I. 2018: A new species of Dignomus Wollaston (Coleoptera: Ptinidae) from Eocene Baltic amber. - Zootaxa 4486(2): 195-200. DOI: https://doi.org/10.11646/zootaxa.4486.2.9

Bukejs, A., Háva J. \& Alekseev, V. I. 2018: New fossil species of Trichodesma LeConte, 1861 (Coleoptera: Ptinidae) from Eocene Baltic amber collected in the Kaliningrad region, Russia. - Paleontologia Electronica 21(2): 1-7. DOI: https://doi.org/10.26879/848

Háva, J. \& Zahradník, P. 2019a: A new Falsogastrallus Pic, 1914 species (Coleoptera: Ptinidae) from Eocene Baltic amber. - Studies and Reports, Taxonomical Series 15(1): 59-62.

Háva, J. \& Zahradník, P. 2019b: Two new species of the genus Xyletinus Latreille, 1809 in Eocene Baltic Amber (Coleoptera: Bostrichoidea: Ptinidae). - Folia Heyrovskyana, Series A 27(2): 13-16.

Háva, J. \& Zahradník, P. 2020a: Three new species of Ptininae (Coleoptera: Bostrichoidea: Ptinidae) from Eocene Baltic amber. - Studies and Reports, Taxonomical Series 16(1): 85-91.

Háva, J. \& Zahradník, P. 2020b: Contribution to the Ptinidae (Coleoptera) from Eocene Baltic amber, with descriptions of two new species. - Folia Heyrovskyana, Series A 28(1): (in press).

LARSSON, S. G. 1978: Baltic amber - a palaeobiological study. - Entomonograph 1: 1-192.

SpAHR, U. 1981: Systematischer Katalog der Bernstein- und Kopal-Käfer (Coleoptera). - Stuttgarter Beiträge zur Naturkunde Serie B (Geologie und Paläontologie) 80: 1-107.

Zahradník, P. \& Háva, J. 2014: New Ptinidae (Coleoptera: Bostrichoidea) from Baltic amber with a list of known fossil species. - Studies and Reports, Taxonomical Series 10(2): 629-646.

Zahradník, P. \& Háva, J. 2017: Three new species of Trichodesma LeConte, 1861 from Baltic Amber (Coleoptera: Ptinidae: Anobiinae). - Folia Heyrovskyana, Series A 25(1): 89-92.

ZAHradník, P. \& HávA, J. 2019: Gastrallus michalskii sp. nov., a new species of tribe Gastrallini (Coleoptera: Ptinidae) from Eocene Baltic amber. - Acta Biologica Universitatis Daugavpiliensis 19(2): 231-233. 